\title{
Analysis of Mathematics Problem Solving Ability of Junior High School Students in Solving Problems in Online Learning
}

\author{
Renita Br Peranginangin', Hardi Tambunan², Suryati Sitepu ${ }^{3}$, Firman \\ Pangaribuan $^{4}$, Dame Ifa Sihombing ${ }^{5}$, Efron Manik ${ }^{6}$, Rick Hunter Simanungkalit ${ }^{7}$ \\ 1,2,3,4,5,6,7 Universitas HKBP Nommensen, Jln. Sutomo, No. 4 Medan, Sumatera Utara
}

\begin{abstract}
This study aims to determine the mathematical problem solving ability of students of SMP Methodist 2 Kisaran in solving story problems with online learning. The method in this study uses descriptive qualitative research methods. The subjects of this study were class VII ${ }^{\mathrm{B}}$ students, totaling 23 students. The data collection technique is a test of students' mathematical problem solving abilities with the material of linear equations and inequalities of one variable and interviews. The results showed that The results of the study indicate that the three levels of problem solving have not been able to go through the stages of re-examining the answers through valid logic and there were differences in the ability to identify elements that were known and asked, there were differences in the ability to choose and apply strategies or problemsolving procedures and there were differences in the ability to examine and explain the results or answers according to problems between students with high, moderate mathematical problem solving abilities. and low. There are $43 \%$ of students who have been able to follow and adapt online learning while $57 \%$ of other students have difficulty understanding the material being taught.
\end{abstract}

Kata kunci: Problem solving ability, story problems, online learning.

\section{Analisis Kemampuan Pemecahan Masalah Matematika Siswa SMP Dalam Memecahkan Masalah dalam pembelajaran Online}

\begin{abstract}
Abstrak
Penelitian ini bertujuan untuk mengetahui kemampuan pemecahan masalah matematis siswa SMP Methodist 2 Kisaran dalam menyelesaikan soal cerita dengan pembelajaran daring. Metode dalam penelitian ini menggunakan metode penelitian deskriptif kualitatif. Subjek dari penelitian ini adalah siswa kelas VII ${ }^{\mathrm{B}}$ yang berjumlah 23 siswa. Teknik pengumpulan data adalah tes kemampuan pemecahan masalah matematis siswa dengan materi persamaan dan pertidaksamaan linear satu variabel dan wawancara. Hasil penelitian menunjukkan bahwa ketiga level pemecahan masalah belum mampu melalui tahapan memeriksa kembali jawabannya melalui logika yang valid dan terdapat perbedaan kemampuan mengidentifikasi unsur-unsur yang diketahui dan ditanyakan, ada perbedaan kemampuan memilih dan menerapkan strategi atau prosedur pemecahan masalah serta ada perbedaan kemampuan memeriksa dan menjelaskan hasil atau jawaban sesuai permasalahan antara siswa dengan kemampuan pemecahan masalah matematis yang tinggi, sedang
\end{abstract}

Universitas HKBP Nommensen

Email: peranginangin.renita@gmail.com
(C)2021 Universitas Islam Negeri Walisongo ISSN: 2088-7868, e-ISSN 2502-5708 
dan rendah. Terdapat $43 \%$ siswa yang sudah dapat mengikuti dan menyesuaikan pembelajaran secara daring sedangkan $57 \%$ siswa lainnya mengalami kesulitan dalam memahami materi yang diajarkan.

Kata kunci: Kemampuan, Pemecahan masalah, Pembelajaran daring.

\section{INTRODUCTION}

Mathematics education research is something that is really needed to be able to provide solutions in terms of problem solving and mathematics learning problems so far and provide new efforts and breakthroughs in developing mathematics education and learning (PeranginAngin et al., 2021). Human knowledge of mathematics is an important role in human civilization so that mathematics is a field of study that must be studied at every level of education in schools. Mathematics learning in schools aims to make students have knowledge, skills and intellectual abilities in the field of mathematics. Yananda \& Salamah, (2014) states that mathematics is a discipline that plays an important role in the progress and development of science and technology. Hidayat, (2011) revealed that by learning mathematics students can practice using their minds logically, analytically, systematically, critically and creatively and have the ability to work together in dealing with various problems and be able to utilize the information they receive.

Based on Permendiknas Number 22 of 2006 concerning Standard Content (SC) Subjects, one of the objectives of learning mathematics is solving problems which include the ability to understand problems, design mathematical models, complete mathematical models, and interpret solutions obtained. Mathematics is also a science that has an important role in shaping the mindset of students, so that students are required to have mathematical abilities as a problem solving tool. This will be realized if students have the right indicators to achieve educational goals, it will produce learning that has good quality, one of which is how students solve math story problems.

Math story problems are a series of math problems in the form of stories that are applied to everyday life. Adams, (2003) also said that story questions can be presented in the form of stories or everyday sentences. In addition, according to to Laily, (2014), story questions are everyday verbal sentences whose meanings from concepts and expressions can be expressed in symbols and mathematical relations. There are several competencies that students must have in finding solutions to the story problems to be solved. First, 
verbal skills, namely the ability to understand problems and interpret them so that they can be transferred into mathematical models. Second, the ability of the algorithm, namely the ability of students to determine the right algorithm in solving problems, the accuracy of calculations and the ability of students to draw conclusions from the results of calculations that students do and relate them to the initial problem to be solved (Rofi'ah et al., 2019).

In mathematics, problem solving is a very important part of the mathematics curriculum because in the learning and completion process, students use the knowledge and skills they already have to apply to problem solving La Misu, (2014). This is in line with the opinion expressed by Ulya et al., (2014) which states that mathematics has a close relationship that cannot be separated from problem solving. Another opinion is also given by Bernard, (2015) which states that problem solving always plays an important role, because mathematical creative activities require problem solving actions.

Problem solving is a learning approach that involves active students optimally which allows students to explore, observe, experiment, and investigate. It aims to facilitate students' understanding of the subject matter obtained as well as supporting media, methods or techniques to make students more active and independent. Arigiyati \& Istiqomah, (2016) problem solving is very important in mathematics, because problem solving is the main thing in improving students' higher-order thinking skills, in order to explore the knowledge and skills they already have to solve problems that students rarely encounter. Problem solving is a goal so that students can more easily apply it with the connection of other sciences to develop in the modern world (Chotimah et al., 2018). Problem solving is an effective approach to teaching higher order thinking processes. In addition, this learning helps students to process ready-made information in their minds and construct their own knowledge about the social world and its surroundings.

According to Suratmi \& Purnami, (2017), the problem-solving ability that students must have is how to overcome problems related to their learning activities, including problem solving on math problems. Problem solving can be said as a learning method that can train and support problem solving skills on math problems in learning activities. Problems in these learning activities can come from the teacher, a phenomenon or everyday problems encountered by students. Problem solving is an important thing in learning mathematics besides problem solving is also a strategic competence shown by 
students in understanding, choosing approaches, solving strategies, and solving models to solve problems. Therefore, students must have ideas or ideas that become problem solving (Bernard, 2015).

Problem solving ability is the potential that a person or student has in solving story problems, solving problems that are not routine (different), applying mathematics in everyday life to find solutions or solve problems in mathematics (Andayani \& Lathifah, 2019). The lack of student problem solving abilities causes students to only be able to work on routine questions or questions that are exactly the same as those given by the teacher, so students are not accustomed to working on non-routine questions which result in students experiencing errors in solving math problems.

Tambunan, (2014) said that problem solving learning in schools is important to improve the mindset and creativity of students. It is hoped that through problem solving activities, mastery of mathematical material and creativity of students will become better and develop. Students are trained to be more critical and analytical of the problems they face, both in solving mathematical problems and even in their daily lives.

At the end of 2019, a deadly infectious virus spread throughout the world called Covid-19 (Corona Virus Disease 2019). The infectious virus that originated in Wuhan, China, has spread to 176 countries and territories. At the beginning of March 2020, things that became a concern for the Indonesian people also happened. President Joko Widodo announced directly that there were two people in Indonesia who had tested positive for the corona virus. Not long after that, on March 12, 2020 WHO (World Health Organization) announced that the corona virus (Covid-19) was a global pandemic outbreak. This greatly affects the world of education, especially the learning process in schools.

The process of learning mathematics in schools can be done in two ways, namely conventional learning and online learning. Learning mathematics conventionally is by learning face-to-face in class. In conventional learning methods, the teacher acts as a provider of information through lectures and students tend to be passive in receiving subject matter. With this kind of learning, the participation and activeness of students in participating in the learning process is not optimal. Online learning (also known as online learning, or e-Learning) is the result of a learning delivered electronically using computers and computer-based media. The material is often accessed via a network. 
After the WHO announced Covid-19 as a global pandemic, several countries have taken preventive measures, one of which is social distancing (maintaining social distance) and physical distancing (maintaining physical distance). In this case, Indonesia has also taken preventive measures by maintaining social distance. President Joko Widodo in his speech invited Indonesians to work, study and worship from home. Therefore, the Ministry of Education and Culture as well as several regional officials issued a policy in terms of changing the implementation of conventional teaching and learning activities to online so that students can still learn even though they are not in school for the safety of many people.

E-learning is also used as a very useful online information source because elearning does not have to be face-to-face (Lane, 2016). This is in accordance with the opinion put forward by (Hong et al., 2018) that E learning is used as independent learning for students. Even though the mathematics learning process is carried out online, it must still pay attention to the objectives of learning mathematics. One of the objectives of learning Mathematics is to develop students' mathematical problem solving abilities. Arifin, (2017) stated that the objectives of learning mathematics in the 21 st century are known as the $4 \mathrm{C}$ characteristics, namely Communication, Collaboration, Critical Thinking and Problem Solving, Creativity and Innovation.

To measure students' mathematical problem solving abilities, indicators are needed as a reference for assessment. According to Suherman, (2003) states that the steps that must be taken in solving mathematical problems are:

1. Present the problem in a clear form.

2. State the problem in an operational form.

3. Develop alternative hypotheses and work procedures that are expected to be good.

4. Testing hypotheses and doing work to get the results.

5. Re-check the results obtained

According to Biró \& Csernoch, (2015) the problem solving steps contained in the book "How to Solve It" include:

1. Understand the problem.

2. Planning a solution.

3. Solve problems according to plan.

4. Recheck the results obtained. 
The process carried out at each step of solving this problem is described as follows Biró \& Csernoch, (2015):

1. Understanding the Problem.

Without an understanding of the given problem, students may not be able to solve the problem correctly.

2. Planning Completion.

The ability to plan this solution is very dependent on the experience of students in solving problems. In general, the more varied their experiences, the more creative students tend to plan to solve a problem.

3. Solving Problems According to Plan.

Students solve problems according to the steps that have been planned.

4. Rechecking the results obtained.

Re-checking all the steps that have been done from the third completion phase. In this way, various unnecessary errors can be corrected again so that students can arrive at the correct answer according to the problem given.

Indicators of problem solving ability according to NCTM Riani, (2014) are:

1. Investigate and understand the content of mathematics.

2. Implement a combination of mathematical problem solving strategies.

3. Recognize and formulate problems from the given situation.

4. Applying processes from mathematical models to real-world situations.

Indicators of solving mathematical problems according to Riani, (2014) include:

1. Identify the elements that are known, which are asked and the adequacy of the elements needed.

2. Formulate a mathematical problem or develop a mathematical model.

3. Applying strategies to solve various problems (types and new problems) in or outside mathematics.

4. Explain or interpret the results of the original problem.

5. Use mathematics in a meaningful way.

Based on the explanation above, it can be concluded that the indicators of solving mathematical problems in this study are: 
1. Able to identify or understand problems.

2. Able to plan solutions.

3. Able to solve problems according to plan.

4. Able to re-check the results of the solution.

This study aims to determine the mathematical problem solving ability of students in the online learning process. The results of this study are expected to provide input to researchers related to students' mathematical problem solving abilities in online learning and can assist teachers in providing alternative learning models for students in analyzing students' weaknesses and strengths in order to achieve good students' mathematical problem solving abilities later.

\section{RESEARCH METHODS}

This research method uses descriptive qualitative research methods. Arikunto, (2010) descriptive research is research that aims to determine the circumstances and conditions in which the results are described in the form of a research report. The purpose of this study was to determine the students' mathematical problem solving ability in solving story problems and to find out the factors that could influence it. This research was carried out at Methodist Middle School 2 Kisaran, Asahan Regency, North Sumatra Province in April 2021. The subjects of this research were the seventh grade students of Kisaran Methodist Middle School, totaling 23 students who were the main informants. The selection of subjects in this study was carried out by selecting 6 students as representatives of each level of knowledge of the results of the given mathematical problem solving ability test by using purposive sampling method.

The instruments used in this study were: (1) The mathematical problem solving ability test given to students consisted of 4 questions describing the material equations and linear inequalities of one variable. (2) Interviews with students with low scores (6 students). (3) Interviews with teachers regarding students' mathematical problem solving abilities. To check the validity of the result of the analysis, a triangular method was conducted by interviewing each subject.

\section{RESULTS AND DISCUSSION}

The Response Questionnaire was given to class VII.B students in the form of a 
google form. This response questionnaire consists of 16 statements. With the results of calculations using a Likert scale. The attitude objects that are assessed are (1) students' attitudes towards online math lessons; (2) students' interest in online learning; (3) Student's response to the problem of mathematical problem solving ability. The results of calculations carried out per statement item in the form of a percentage, to show student responses to online learning, which can be seen in table 1.3.

Table 1.3. Result of Calculation of Student Response Questionnaire

\begin{tabular}{ccccc}
\hline & \multicolumn{4}{c}{ Answer Options } \\
Statement Number & SA $(\%)$ & A $(\%)$ & DA $(\%)$ & SDA $(\%)$ \\
\hline 1 & 13,04348 & 39,13043 & 30,43478 & 17,3913 \\
2 & 17,3913 & 47,82609 & 30,43478 & 4,347826 \\
3 & 13,04348 & 47,82609 & 30,43478 & 8,695652 \\
4 & 21,73913 & 30,43478 & 34,78261 & 13,04348 \\
5 & 21,73913 & 17,3913 & 21,73913 & 39,13043 \\
6 & 26,08696 & 26,08696 & 26,08696 & 21,73913 \\
7 & 8,695652 & 43,47826 & 43,47826 & 4,347826 \\
8 & 13,04348 & 47,82609 & 34,78261 & 4,347826 \\
9 & 8,695652 & 52,17391 & 26,08696 & 13,04348 \\
10 & 13,04348 & 43,47826 & 21,73913 & 21,73913 \\
11 & 8,695652 & 47,82609 & 26,08696 & 17,3913 \\
12 & 17,3913 & 17,3913 & 52,17391 & 13,04348 \\
13 & 13,04348 & 39,13043 & 34,78261 & 13,04348 \\
14 & 21,73913 & 30,43478 & 39,13043 & 8,695652 \\
15 & 13,04348 & 17,3913 & 47,82609 & 21,73913 \\
16 & 13,04348 & 39,13043 & 30,43478 & 17,3913 \\
\hline
\end{tabular}

Based on the first observed aspect, namely students' attitudes towards online mathematics lessons, $39.13 \%$ of students responded positively and $60.86 \%$ of students responded otherwise. This means that there are still many students who do not understand the material being taught when online learning is applied and when they have difficulty in answering the assignments given by the teacher, they only need to wait for answers from friends rather than looking for other solutions. This is because learning mathematics online is new for students, but besides that, some students find new knowledge that has not been obtained from face-to-face learning and students can learn anywhere and anytime as long as online learning is applied. The results of the calculation of the student response questionnaire for statement 3 which revealed that with online learning, students were motivated to learn mathematics, as many as 3 students (13.04\%) strongly agreed, 
11 students $(47.82 \%)$ agreed, 7 students $(30,43 \%)$ disagreed, and 2 other students $(8.69 \%)$ strongly disagreed. Statement 9 which states that online learning makes students interested in learning mathematics, obtained as many as 2 students (8.69\%) strongly agree, 12 students (52.17\%) agree, 6 students (26.08\%) disagree, and 3 students $(13.04 \%)$ strongly disagree.

Based on the second observed aspect, namely student interest in online learning, it was found that $60.86 \%$ of students responded positively and $39.13 \%$ of students responded otherwise. This means that some students have a fairly high enthusiasm for learning mathematics online, but there are still students who are less interested in participating in online learning. This is influenced by several factors including: a) technical constraints, such as network quotas; b) online learning puts pressure on students because the tasks given are more than face-to-face learning; c) monotonous learning makes students less happy with online learning; d) students are not happy because they cannot meet their friends. Based on the third observed aspect, namely students' attitudes towards mathematical problem solving abilities, it was found that $73.91 \%$ of students responded positively and $26.08 \%$ responded otherwise. This means that most students have been able to solve mathematical problem solving skills well even though the learning is carried out online and there are only a few students who still find it difficult to solve problem solving ability questions because they cannot ask or ask for help from friends directly.

The results of the mathematical problem solving ability test of the selected sample can be seen in table 1;

Table 1. The results of the selected sample mathematical problem solving ability test

\section{Mathematical Problem Solving}

\begin{tabular}{cccccccc} 
Nu & Level & Code & $\mathbf{1}$ & $\mathbf{2}$ & $\mathbf{3}$ & $\mathbf{4}$ & $\begin{array}{c}\text { Total } \\
\text { Score }\end{array}$ \\
\hline 1 & High & S-11 & 10 & 10 & 10 & 8 & 38 \\
2 & Medium & S-04 & 0 & 8 & 5 & 8 & 23 \\
3 & Low & S-01 & 4 & 0 & 0 & 0 & 4 \\
\hline
\end{tabular}

Inf: SMI : 40

The table above is a sample of the results of the mathematical problem solving ability test in class VII.B. From each test, it can be seen that there are differences in the 
scores based on the level of problem solving ability. Students who were selected as the chosen sample then entered the interview stage to collect in-depth information that was useful to assist in the data analysis process. At the time of data description of mathematical problem solving ability, students are separated based on the level of solving ability the problem. For each level, 2 students were chosen to describe the answer data.

The results of the mathematical problem solving ability test given to 23 students taking the mathematical problem solving ability test as research subjects are as follows. Table 1.2

Table 1.2. Mathematical Problem Solving Ability Test Results

\begin{tabular}{clcc}
\hline Nu & Level & Sum of Students & Percentese \\
\hline 1 & High & 5 & 21,73 \\
2 & Medium & 11 & 47,82 \\
3 & Low & 7 & 30,43 \\
\hline
\end{tabular}

From the table above, it can be seen the percentage of students in each mathematical problem solving ability, where $21.73 \%$ of students are in the high category, $47.82 \%$ of students are in the medium category, and $30.43 \%$ of students are in the low category.

The mathematical problem solving ability of high category students can be analyzed based on the results of test answers and interviews that have been conducted. The analysis was carried out per indicator of students' mathematical problem solving ability. on the results of the test, it was found that students with high-level problem-solving abilities were able to write down what was known and asked about the questions correctly without any confusion in the sentences written.

Based on the results of the interviews, it was shown that students with high mathematical problem solving abilities already understood the information contained in the questions, were able to identify problems, plan and implement solutions and were able to check the results of the completion correctly and thoroughly so as to obtain correct, clear and complete answers. This is because students can determine the formula based on the problem given correctly and marked by the operations performed after almost all of the formulas are correct and find the results. Based on the results of interviews with highlevel students, it shows that students already understand the information contained in the questions, are able to understand problems, plan and implement solutions and are able to re-examine the results of the settlement so that they obtain correct, clear and complete answers. 
Intermediate Mathematical Problem Solving Skills (S-04) was appointed to represent 11 students in the medium category, because the answers S-04 represented all the same students in the medium category. The following is the result of S-04's answer. At this stage, researchers will see the extent to which students' ability to identify the elements that are known and asked and the adequacy of the elements needed so that students can carry out to the next stage, namely, planning and implementing strategies or solving procedures. S-04 in identifying elements that are known and asked by reading and understanding the problem is done directly and writes down what is known and asked in the problem, but there are a few elements that are not written down as reasons for solving. But in the fourth problem, students with moderate problem solving skills have been able to write down problem information well. S-04 runs problem number two with the correct steps. Based on the answers above, S-04 is able to apply a problem-solving strategy by writing the formula used in solving the problem correctly, namely the formula to determine the amount of bread that must be sold so that the factory does not lose and can explain well the completion procedure. The results of the answer S-04 number three can be seen in Figure 1 as follows:

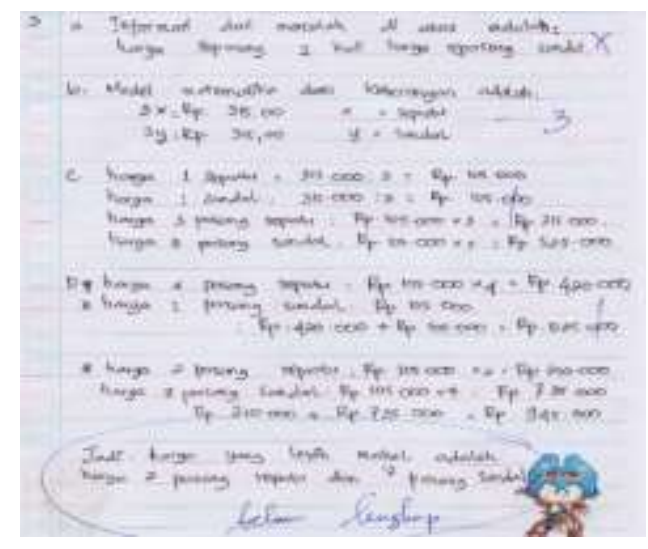

Figure 1. The results of the answer S-04 number three

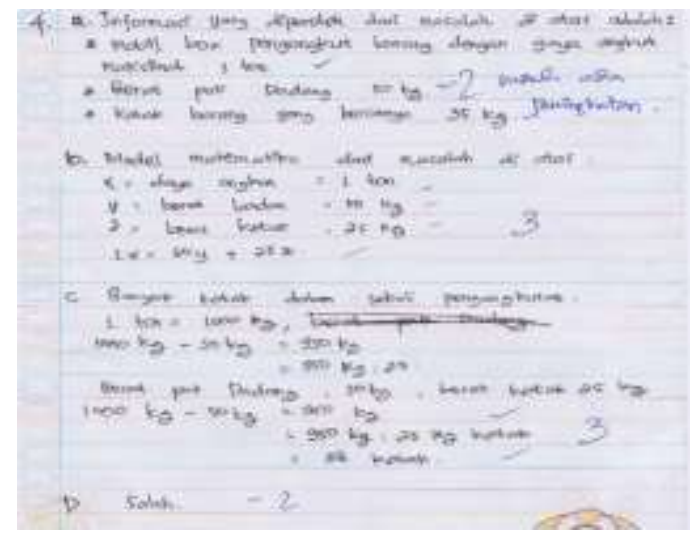

Figure 2. The answer from S-04 number four

At this stage students are expected to try to check and explain the truth of the results or answers according to the problems asked carefully. Thus, errors and errors in understanding information and solving problems can be found. Based on Figure 3, S-04 worked on question number three with inaccurate steps, this was due to S-04's mistake in writing the formula to prove the information in the picture so that the proof of examination and explanation was less precise. The way that can be done to check the correctness of 
the answer is by understanding the information on the question, checking its correctness, then checking step by step in the completion that has been written.S-04 works on question number four with complete and correct steps. Based on the answers above, S-04 is able to identify the elements that are known and asked clearly and completely. Able to apply appropriate strategies or solving procedures, obtain correct, clear and complete answers. However, S-04 was not able to provide a reason for solving the problem in question. Seen in answer number 4 part d, S-04 did not write down the evidence according to the problem being asked.

Based on the results of the test and interview answers, it was found that students with moderate level problem solving abilities were able to write down the things that were known and asked from the questions correctly without any confusion in the sentences written. Based on the results of interviews with students, it shows that students already understand the information contained in the questions, are able to mention what is known and asked in the questions. Able to provide further explanation regarding the information contained in the question.

Students with moderate level problem solving skills are able to apply appropriate strategies or solving procedures, obtain correct, clear and complete answers. This is because students can determine the formula based on the problem given correctly and marked by the operations performed after almost all of the formulas are correct and find the results. Based on the results of interviews with moderate-level students, it shows that students already understand the information contained in the questions, are able to choose and apply problem-solving strategies using the procedures requested correctly. Able to act by providing further explanations and able to combine sources with the completion process and can mention the sequence in solving problems correctly. Students with moderate-level problem-solving skills have not fully mastered the third problem-solving indicator. It is proven by an error in writing a formula when trying to prove a statement in a question, middle-level students are considered to still have not been able to check and explain the truth of the results or answers according to the problems asked. After going through the interview stage, it was found that the intermediate level students were not careful in reading the questions.

Low Level Mathematical Problem Solving Ability (S-01) was appointed to represent 7 students in the very low category, because the answers S-01 represented all 
the same students in the very low category. The following is the result of S-01's answer. At this stage, researchers will see the extent to which students are able to identify the elements that are known and asked and the adequacy of the elements needed so that students can carry out to the next stage, namely, selecting and implementing strategies or problem-solving procedures. Based on the answers above, S-01 is able to state what is known but is not clear and is unable to formulate questions by not writing down what was asked in words. The results of the answers S-01 numbers one and two can be seen in Figure 3 as follows.

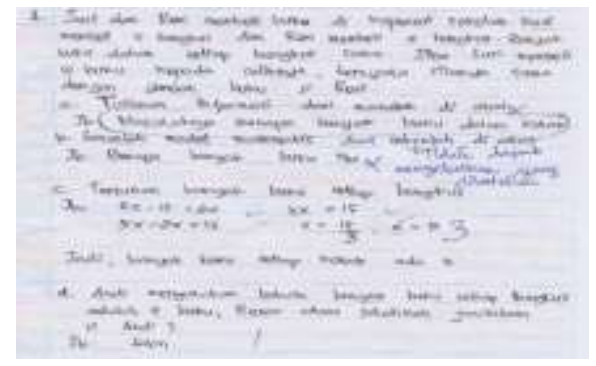

Figure 3. The results of the answers numbers one and two

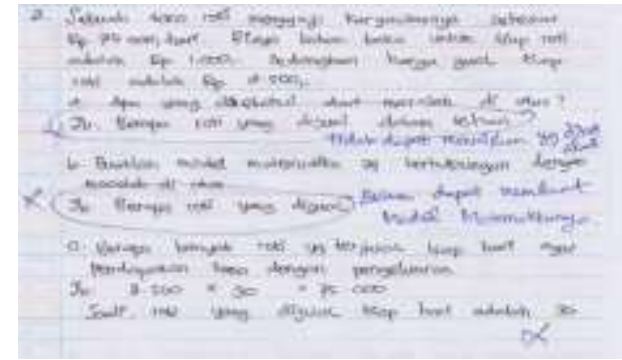

S-01 Figure 4. The results of the answers to S-01 numbers three and four

At this stage the researcher will see the extent to which students' abilities in choosing and implementing problem solving strategies or procedures to get answers based on the problems given. S-01 works on question number two with steps that are not precise and not neat. Based on the answers above, S-01 is less able to apply problem solving strategies so that he gets the wrong answer. Stage students are expected to try to check and explain the truth of the results or answers according to the problems asked carefully. Thus, errors and errors in understanding information and solving problems can be found. S-01 worked on question number three with steps that were not quite right. Based on the answers above, S-01 is not able to explain the truth of the results or answers according to the problems asked.

The results of the answers to tests and interviews that have been carried out show that students with low-level problem-solving abilities are able to state what is known but is not clear and unable to formulate questions by not writing down what is asked in words. Based on the results of interviews with students, it shows that students with low-level mathematical problem solving skills in reading and understanding the problem are done directly without writing down what is asked on the answer sheet. Students with low-level problem-solving skills are less able to apply problem-solving strategies. This can be seen 
in the answers to questions number 2 and number 4 part $b$, it can be seen that students are less precise in determining the formula to work on the problem so that they get the wrong answer. After going through the interview stage, it is known that students cannot mention the correct formula to solve problems number 2 and $4 \mathrm{~b}$ and find findings that students have weaknesses in terms of remembering formulas.

Students with low-level problem-solving skills are not able to master the fourth problem-solving indicator, namely checking and explaining the truth of the results or answers according to the problems asked. This can be seen in the answer to question number 3 there is no proof of examination and correct explanation while in number $4 \mathrm{~d}$ students do not answer the question because they do not understand it. Based on the results of interviews with students, it shows that students have not been able to check the truth of the statements contained in the questions. So that he felt the answer was right but it turned out that his work was still wrong. After reading and understanding the information contained in the questions, students should be able to check and explain their respective answers, of course, by accompanying the examination evidence and explanations.

The results of the study indicate that the three levels of problem solving have not been able to go through the stages of re-examining the answers through valid logic, contrary to the results of Adnyani \& Agustiana, (2021) research which states that the high score problem-solving ability score is able to go through the stages of re-examining well, According to research Utami \& Wutsqa, (2017), Students with high self-confidence who have problem-solving skills at a moderate level have not been able to evaluate the results of their work properly.

\section{CONCLUSION}

Based on the results of the research and discussion in this study, it can be concluded that the mathematical problem solving abilities of students at SMP Methodist 2 Kisaran, Asahan Regency are as follows: (1) Based on the results of the analysis, it is found that students with high level problem solving abilities are able to identify elements that known and asked, as well as the adequacy of the required elements in a clear and complete manner; can choose and apply the right strategy or solution procedure, obtain correct, clear and complete answers; less able to check and explain the truth of the results or 
answers that are in accordance with the problem through valid logic; (b) Students with moderate level of mathematical problem solving skills are able to identify the elements that are known and asked about, as well as the adequacy of the required elements in a clear and complete manner; have good ability in selecting and implementing problem solving strategies or procedures; less able to check and explain the truth of the results or answers that are in accordance with the problem through valid logic; (c) Students with low-level mathematical problem solving skills are still somewhat less able to identify elements that are known and asked; the ability to choose and implement strategies or problem solving procedures is still not well honed; the ability to examine and explain the results or answers according to the questions asked is still very low..

\section{DAFTAR PUSTAKA}

Adams, T. L. (2003). Reading mathematics: More than words can say. The Reading Teacher, 56(8), 786-795.

Adnyani, N. N. T., \& Agustiana, I. G. A. T. (2021). An Active Learning Process by Using Media Fun Thinkers" Weather". Jurnal Ilmiah Sekolah Dasar, 5(3).

Andayani, F., \& Lathifah, A. N. (2019). Analisis kemampuan pemecahan masalah siswa smp dalam menyelesaikan soal pada materi aritmatika sosial. Jurnal Cendekia: Jurnal Pendidikan Matematika, 3(1), 1-10.

Arifin, J. (2017). SPSS 24 untuk Penelitian dan Skripsi. Elex Media Komputindo.

Arigiyati, T. A., \& Istiqomah, I. (2016). Perbedaan Kemampuan Pemecahan Masalah Dengan Pembelajaran Learning Cycle Dan Konvensional Pada mahasiswa Prodi Pendidikan Matematika FKIP UST. Union: Jurnal Ilmiah Pendidikan Matematika, $4(1)$.

Arikunto, S. (2010). Metode peneltian. Jakarta: Rineka Cipta.

Bernard, M. (2015). Meningkatkan kemampuan komunikasi dan penalaran serta disposisi matematik siswa SMK dengan pendekatan kontekstual melalui game adobe flash cs 4.0. Infinity Journal, 4(2), 197-222.

Biró, P., \& Csernoch, M. (2015). The mathability of computer problem solving approaches. 2015 6th IEEE International Conference on Cognitive Infocommunications (CogInfoCom), 111-114.

Chotimah, S., Bernard, M., \& Wulandari, S. M. (2018). Contextual approach using VBA learning media to improve students' mathematical displacement and disposition ability. Journal of Physics: Conference Series, 948(1), 12025. 
Fauzan, A., \& Arnawa, I. M. (2020). Designing mathematics learning models based on realistic mathematics education and literacy. Journal of Physics: Conference Series, 1471(1), 12055.

Hidayat, W. (2011). Meningkatkan Kemampuan Berpikir Kreatif Matematik Siswa Sekolah Menengah Atas Melalui Pembelajaran Kooperatif Think-Talk-Write (TTW). Susunan Tim Penyunting, 51.

Hong, N. T. T., Giang, T. T., Phuong, N. N., \& Khanh, M. Q. (2018). The Status of Applying E-Learning in Holding Students' Self-Study of the Subject Education in Pedagogical Universities In Vietnam. American Journal of Educational Research, 6(6), 804-810.

La Misu, M. P. (2014). Mathematical problem solving of student by approach behavior learning theory. This Paper Has Been Presented at International Seminar on Innovation in Mathematics and Mathematics Education, Yogyakarta, Indonesia.

Laily, I. F. (2014). Hubungan kemampuan membaca pemahaman dengan kemampuan memahami soal cerita matematika sekolah dasar. Eduma: Mathematics Education Learning and Teaching, 3(1).

Lane, S. (2016). Effective online discussion forums as a legal learning space. American Journal of Educational Research, 4(5), 392-396.

PeranginAngin, R. B., Panjaitan, S., Hutauruk, A., Manik, E., \& Tambunan, H. (2021). Arah dan Trend Penelitian Pendidikan Matematika di Jurnal Riset Pendidikan Matematika (JRPM). Vygotsky: Jurnal Pendidikan Matematika Dan Matematika, 3(1), 49-62.

Riani, E. (2014). Pengaruh Gaya Belajar Terhadap Prestasi Belajar Siswa Pada Mata Pelajaran Matematika Kelas VII SMP N 2 Sruweng Tahun Pelajaran 2012/2013. Pendidikan Matematika-FKIP.

Rofi'ah, N., Ansori, H., \& Mawaddah, S. (2019). Analisis kesalahan siswa dalam menyelesaikan soal cerita matematika berdasarkan langkah penyelesaian polya. EDU-MAT: Jurnal Pendidikan Matematika, 7(2).

Suherman, E. (2003). Strategi pembelajaran matematika kontemporer. Bandung: Jica.

Suratmi, S., \& Purnami, A. S. (2017). Pengaruh strategi metakognitif terhadap kemampuan pemecahan masalah matematika ditinjau dari persepsi siswa terhadap pelajaran matematika. UNION: Jurnal Ilmiah Pendidikan Matematika, 5(2).

Tambunan, H. (2014). Strategi heuristik dalam pemecahan masalah matematika sekolah. Jurnal Saintech, 6(4), 35-40.

Ulya, H., Kartono, A. R., \& Retroningsih, A. (2014). Analysis of mathematics problem 
solving ability of junior high school students viewed from students' cognitive style. Journal of Education and Practice, 2(10), 577-582.

Utami, R. W., \& Wutsqa, D. U. (2017). Analisis kemampuan pemecahan masalah matematika dan self-efficacy siswa SMP negeri di Kabupaten Ciamis. Jurnal Riset Pendidikan Matematika, 4(2), 166-175.

Yananda, M. R., \& Salamah, U. (2014). Branding tempat: membangun kota, kabupaten, dan provinsi berbasis identitas. Makna Informasi. 
Renita Br Peranginangin, dkk/ Phenomenon Vol. 11, No. 2, Oktober 2021 